Ульфат Бадалбейли

Бакинский государственный университет Азербайджан

https://doi.org/10.18485/ai_savremeni_roman.2020.ch3

821.163.41.09 Андрић И.

Оригинални научни рад

\title{
МОТИВ «МОСТА» \\ В ТВОРЧЕСТВЕ ИВО АНДРИЧА
}

В этой статье изучаются работы удивительного художника - реалистического и психологического мастера прозы, мыслителя и успешного дипломата, лауреата Нобелевской премии (1961) Иво Андрича.Богатое литературное наследие Иво Андрича, включая поэзию, прозу, эссе, представляет собой прекрасное органический сплав проблем, проблем и видений одной из самых интересных и своеобразных провинций Боснии.

Автор книги «Мост на Дрине» изучал универсальные человеческие проблемы, выходя за рамки национальной реальности. Писатель ищет смысл существования человечества во всех своих композициях. Он писал о вечном стремлении людей понять, как реальность должна быть и как люди сами должны быть.

Произведения Иво Андрича хорошо известны в азербайджанских литературных исследованиях. Лекции о работах Иво Андрича, Мешы Селимович и других балканских писателей читаются на гуманитарных факультетах Бакинского государственного университета.

Ключевые слова: балканская литература, роман, мотив, мост, Травник, Вышеград, Нобелевский лауреат, ИвоАндрич, мировая живопись, переводы, азербайджанское литературоведение. 
«Повествователь и его творение не служат ничему, если тем или иным способом не служат человеку и человечеству.»

Иво Андрич

Творческий путь замечательного художника - peaлиста, мастера психологической прозы, своеобразного мыслителя, успешного дипломата, лауреата Нобелевской премии (1961) Иво Андрича, охватывает более 60 лет. Андрич относится к тем писателям XX века, на судьбу и творчество которых наложили жестокий отпечаток обе мировые войны.

Обширное литературное наследие Иво Андрича, включающее поэзию, прозу, эссеистику представляет удивительно органический сплав проблем, тем, образов, порожденных действительностью одного из самых интересных и своеобразных краев Боснии. Остро ощущая свою привязанность к земле, на которой он родился и вырос - Травнику, Вышеграду, Сараево, он, еще будучи начинающим писателем, чувствовал, какие живительные силы дает литературе ее национальная первооснова, любовь к своей Земле, духовному «наследию» предков.

Несмотря на долгое отсутствие - годы учебы, дипломатическая служба во многих странах Европы, поездки - все, созданное им связано с Боснией. На исторической судьбе своей родины автор «Моста на Дрине» исследовал общечеловеческие проблемы, выходя далеко за пределы национальной действительности. Во всех своих произведениях писатель искал смысл существования человека, смысл «великой и переменчивой и вечно одинаковой драмы человеческого существования» под властью суровой действительности, а также писал о вечном 
стремлении людей понять, какой должна быть эта действительность и какими должны быть сами люди.

Историк по образованию, Андрич считал, что в решении художественных задач, стоящих перед писателями, следует обращаться к первоэлементам истории - легендам, сказаниями преданиям своего народа, высоко ставил «сказку народа о себе», и был уверен, что только изучив этот пласт культуры можно узнать и прошлое, и настоящее, и будущее.

В эссе «Разговор с Гойей» (1935) Иво Андрич писал, что «... надо слушать легенды - следы вековых коллективных усилий и с их помощью отгадывать, насколько возможно, смысл нашей судьбы. В сказках - подлинная история человечества, в них можно если не постигнуть в полной мере, то почувствовать ее смысл».

В борьбе добра и зла, исконно существующей и никогда не исчезающей в мире, надеждой на лучшее всегда оставались искусство и красота. Вечные, непреходящие ценности Андрич видел в искусстве, будь то искусство зодчества или повествования, живопись или музыка. Жизнь без красоты искусства и без красоты вообще не представляет ценности. Он занимал множество литературных и общественных постов, участвовал во многих политических событиях государственного и европейского масштаба, основал Союз писателей Югославии и был его председателем, депутатом Скупщины Боснии и Герцеговины и Союзной Скупщины, был действительным членом Сербской Академии наук и искусств. Вместе с другими крупнейшими деятелями европейской культуры он стоял у истоков Всемирного движения сторонников мира, был делегатом конгрессов во Вроцлаве (1948) и Париже (1949).

Среди множества наград писателя «Орден почетного легиона» (1933), немецкий орден за заслуги на ди- 
пломатической службе «Немецкий орел» (1937), в 1961 году за роман «Мост на Дрине» Иво Андрич был удостоен Нобелевской премии с формулировкой «За повествовательное искусство прозревающее пространство и время, служащее свободе».

В 2012 году Правительством Сербии и мэрией города Вышеграда была учреждена Премия имени Иво Андрича, которая вручается писателям, пишущим на славянских языках в день получения Андричем Нобелевской премии. В том же, 2012 году в Боснии и Герцеговине произошла закладка города Андричграда на территории Вышеграда. Открытие города состоялось в 2014 году.

В послевоенной прозе Андрича явственно ощущается метафорическое преображение исторической действительности: народно-сказочные и метафорические мотивы, символы, стихотворное слово. Именно глубокое поэтическое чутье стало основой возникновения такого метафорического образа прозы - образа моста.

В знаменитом романе «Мост на Дрине», принесшим автору мировую известность, показана почти полутысячелетняя история подневольной Боснии, закончившейся известным выстрелом 1914 года в Сараево и началом первой мировой войны.

Мотив моста обладал для Андрича особой привлекательностью. Символ моста и история создания мостов уходит корнями в незапамятные времена. Мосты стали возводить уже в микенскую эпоху. Мост - очень положительный символ: это - созидание, налаживание связей, символ будущего, дорога к новой жизни, символ движения.

В мифопоэтической традиции и эзотерике мост выступает прежде всего как образ связи между разными точками сакрального пространства. В этом смысле мост изофункционален пути, точнее, наиболее слож- 
ной его части. Мост мыслиться, обычно, как некая импровизация еще неизвестного, не гарантированного пути. Изображение моста и его символика часто используется в мировой живописи. ${ }^{3}$

Символика моста и лестницы, как связанных между собой понятий, олицетворяет сообщение между небом и землей, между верхним и нижними мирами.

В древнеиранской традиции существовало предание о Мосте Разделения, по которому должны пройти души умерших, чтобы попасть в рай. Для грешников он становился тонким, как лезвие бритвы, а для праведников расширялся. Мост может быть также и радужным, как например мост Биврест (скандинавская мифология) ведущий в Асгард, стражем которого был бог Хеймдаль. ${ }^{4}$

Древние римляне называли верховного жреца понтифик, что буквально переводе означает «строитель мостов», т.е человек, соединяющий два отдельных мира. С середины V века титул «верховного понтифика» стал носить папа римский. Согласно Святому Бернару его призвание заключалось в том, чтобы служить мостом между Богом и человеком. Символика моста связана неразрывно с радугой. Два берега реки, соединенные мостом, олицетворяют два мира: жизни и смерти.

Так как строительство моста несло на себе глубокий символический смысл, то при его возведении приносились жертвы. В Древнем Риме перед началом строительства моста весталки бросали в воду камышовые куклы.

В сознании средневекового европейца строительство арочных мостов казалось невероятно сложным

3 См. Джеймс Холл. Словарь сюжетов и символов в искусстве. Перевод с английского. «Крон-пресс», М. 1999.

4 См: Энциклопедия символов. Под ред., О. В. Перзашкевича. изд-во ЭКСМО. М. 2007. 
делом, и возведение их зачастую приписывали дьяволу. Согласно бытующим в то время легендам, люди обращались за помощью к нечистому, обещая в качестве уплаты душу первого, кто пройдет по мосту. Иногда удавалось одурачить дьявола: так жители Франкфурта пустили по новому мосту петуха. Мост стал символом, как силы дьявола, так и победы над ним человека.

Изображение моста и его символика часто используются в произведениях мировой живописи. ${ }^{5}$

Мотив моста имел для Андрича особую привлекательность. В рассказе «Мост на Жепе» (1925), ставшей наброском к большому полотну «Мост на Дрине», автор прославил красоту создания человеческого разума и человеческих рук.

«Самая прихотливая фантазия не могла представить себе, что в этом диком и разоренном захолустье появится такое чудесное сооружение. Казалось, берега реки бросили друг другу навстречу вспененные струи воды и, соединив их в арку, на единый миг застыли над пропастью, паря в воздухе. В просвете вдали синела Дрина, а глубоко внизу бешено пенилась укрощенная Жепа.» ${ }^{6}$

В эссе «Мосты» (1933) он выразил свое убеждение, что мосты «важнее, чем дома,священнее, чем храмы, ибо они общие».

Частые поездки по многим странам и наблюдение мостов во Франции, Испании, Италии, Турции стали для писателя выражением извечного стремления человека преодолеть "раздел, противоречия и разлуку». Мимо моста нельзя пройти без внимания, говорится в эссе, «ибо он указывает место, где человек наткнулся

5 См. Джеймс Холл. Словарь сюжетов и символов в искусстве. Перевод с английского. «Крон-пресс», М. 1999.

6 Иво Андрич. Повести и рассказы. Мосты на Жепе. Серия «Мастера современной прозы». Изд., М., Радуга. 1983. с. 50. 
на препятствие и не остановился перед ним, но преодолел его и перебросил через него мост».

Знаковый в глубоких раздумьях писателя о феномене моста, мост в романе «Мост на Дрине» становиться метафорой времени, олицетворением самой истории, символом человеческого единения. Это была счастливо найденная формула смысла исторического существования человека, о котором так много размышлял писатель.

Мост воздвиг великий визирь Мехмед-паша, чье родное село Соколовичи находится неподалеку от моста за одной из окрестных гор. Поставил же его Раде Строитель, легендарный и воистину безымянный зодчий. Автор рассказывает интересную легенду о том, «что русалка, хозяйка реки, воспротивилась строительству моста, как испокон веков противятся неведомые силы всякому строительству, - ночью рушила воздвигнутое днем.

Так продолжалось до тех пор, пока Раде Строителю не был голос из воды и дал ему совет - сыскать двух новорожденных близнецов, брата и сестру, Стою и Остою, и замуровать их в средние опорные быки. Стражники отыскали в одном глухом селении близнецов, грудных младенцев и, силой отобрав их у несчастной матери, привезли на стройку. Младенцы были замурованы, но Раде Строитель по преданию внявстенаниям безумной матери, оставил отверстия в опорных столбах, через которые мать могла кормить детей грудью. Как память о давно минувшем, несколько сотен лет из этих отверстий струиться материнское молоко. Соскабливая эти молочные потеки с опорных столбов люди продают полученный порошок как целебное средство не имеющим молока женщинам. ${ }^{7}$

7 Иво Андрич. Мост на Дрине. Изд-во «Правда». М. 1985, с. 9. 
Сюжет романа отличается большой силой концентрации, показывающей и общенародные события, и отдельные судьбы, так или иначе, связанные с мостом. Мост - центр не только сюжетный, но и смысловой, поэтически возвышенный центр романа.

«Ворота венчают мост, а мост, в свою очередь, венчает город ворота сии поистине сердце моста, а мост сердце города, город же, увиденный раз, поистине останется в сердце у каждого».

Много ли на свете визирей и богачей, которые в радости и в печали, и в сладостном безделье и в праздности могли бы прийти в такое место? ... в бесконечных бдениях на мосту следует искать причину склонности многих горожан к мечтам и раздумьям, как и главную разгадку меланхолической беспечности, отличающей жителей Вышеграда. ${ }^{8}$

Образ моста на Дрине, воссоединяющего два берега, две культуры, две цивилизации, две ветви одного народа, стал своеобразным фокусом, символом всего дальнейшего творчества Иво Андрича.

В сознании черноволосого мальчика безмолвно сидящего в одной из переметных корзин, которых вместе с другими сербскими детьми увозили янычары насильно из Боснии, для службы в Османскую армию, возникло видение моста. Видение было вызвано мрачной безысходностью поросшего уныло-серыми ракитами скалистого берега, безобразностью паромщика и оплетенной паутиной мельницы в которой пришлось заночевать в ожидании очереди переправки через мутную Дрину, оглашаемую карканьем ворон.

Мутная Дрина, подобно черной черте разделила край, где он родился и чужую землю, где он получил

8 Там же, с.14-15. 
другое имя, принял другую веру, стал могущественным визирем, но боль разлуки с родной землей не утихала в его груди никогда. Избавлением от нее представлялся ему мост над рекой, который соединит ее берега и навсегда свяжет его родину с краем, где прошла его жизнь. Так мост, построенный велением могущественного визиря Мехмед-пашой Соколи становиться поэтическим воплощением исторической трагедии Боснии, отразившейся в человеческих судьбах. ${ }^{9}$

Вот почему повесть о рождении и судьбе моста есть в то же время повестью о судьбе города и многих поколений его обитателей, и наоборот, все устные предания о жизни города пронизывает линия каменного моста с его одиннадцатью арками и короной ворот посередине. ${ }^{10}$

Политические и социальные события, происходящие в течение столетий, свидетелями которых становится мост на Дрине - победоносные турецкие походы, бунты непокорных, наводнения и эпидемии, национально освободительное восстание 1875-1878 годов, изгнание турок и новая австро-венгерская оккупация - это реальная история и мост полноправный участник движения этого процесса.

Нельзя не обратить внимания на концовки глав романа, указывающих на непоколебимость моста: «... ни долгие годы, ни столетия, ни жесточайшие столкновения людей не меняли моста. Все это проносилось над ним точно также, как быстрая река под его гладкими прекрасными арками.

«В череде перемен и стремительно отцветающих людских поколений он оставался неизменным, подобно реке, текущей под ним.. Его век, хотя мост сам по

9 Иво Андрич. Мост на Дрине. Изд-во «Правда». М. 1985, с. 20.

10 Там же, с.16. 
себе и был смертен, представлялся беспредельным, потому, что конец его не был виден». ${ }^{11}$

Именно, в «Мосте на Дрине» писатель укрепился в вере, что «жизнь необъяснимое чудо, что уходя и отцветая, она все же остается нерушима и стойка, «как на Дрине мост». ${ }^{12}$

В романе звучит еще одна, очень характерная для мировоззрения и творчества Андрича мысль о красоте, во все времена сопровождающая и необходимая людям.

В Советском Союзе Андрич впервые побывал в апреле-мае 1946 года в составе представительной делегации Югославской общественности, приглашенной ВОКСОМ. Делегация посетила Москву, Ленинград, Сталинград, Киев, Тбилиси, и некоторые другие города. В ноябре 1946 года Андрич был избран заместителем председателя Общества культурной связимежду Югославией и СССР и через несколько дней председателем Союза писателей Югославии. В сентябре 1947 года Андрич участвовал в праздновании восьмисотлетия Низами, был снова в Москве, Ленинграде, Сталинграде, а также в Баку и Гяндже (тогда Гянджа была переименована в Кировабад). Свои впечатления он передал в очерках «На Невском проспекте», «Впечатления о Сталинграде», «Поездка в Грузию», «Поездка в Азербайджан».

Творчество Иво Андрича достаточно известно в азербайджанском литературоведении. В общем курсе истории мировой литературы на гуманитарных факультетах Бакинского Государственного Университета читаются лекции о творчестве Иво Андрича, Меши Селимовича и других балканских литераторах преды-

11 Иво Андрич. Мост на Дрине. Изд-во «Правда». М. 1985, с. 17.

12 Там же, с. 81. 
дущих периодов. Довольно часто осуществляются переводы балканских авторов. Так, писателем и литературоведом Алекпером Салахзаде был сделан перевод на азербайджанский язык романа Меши Селимовича «Дервиш и смерть» опубликованной в издательстве «Progres» в 2012 году и номинированный на премию им Аббаса Сиххата. Известный, и, справедливо было бы отметить, единственный азербайджанский славист и балканист, доктор филологических наук, заведующий кафедрой мировой литературы Бакинского Государственного Университета профессор Джалил Нагиев систематически занимается исследованием и переводами из сербохорватской литературы.

В его переводах в годовом сборнике переводов «Dünya» («Мир») в II выпуске за 1986 год, вышедшим в издательстве «Yazıçı» опубликован перевод с сербскохорватского рассказа «Волчица». В 1990 году в издательстве «Гянджлик» опубликован перевод произведения «Размышления» Иво Андрича (стр. 181-183); в 2016 году журнале «Dünya» (әdəbiyyət dərqisi) опубликованы три рассказа Иво Андрича, в том числе рассказ «Путь Алии Джерзелеза» (стр. 223-240). В нынешнем, 2019 году им же осуществлен и издан перевод замечательного романа Иво Андрича «Мост на Дрине» издательством «Azərbaycan tərcümə Mərkəzi» (432 стр). Перевод профессора Джалила Нагиева отличает достоверностью и близость к тексту оригинала, глубокая художественность, проникновенность в материал и эпоха создания романа. В переводе удивительно сохранен дух, эстетика, изумительная отточенность в изображении характеров, ситуации, времени и реалии, мусульманский дух, природа, изображенные в оригинале. Перевод читается на одном дыхании. 
«Андрич - правдивый свидетель, а его слова - прекрасное свидетельство духовной и нравственной истории нашей страны, нашего стремления к жизни без зла, наших поисков правильного пути. Связанные с живой жизнью своего времени и своего народа, романы и рассказы Андрича сверкают вечной юностью совершенного замысла и величественных, благих творений человеческих рук, не ведающих старости и перемен, и не подверженных судьбе преходящих явлений этого мира». Ибо, произведения Андрича - такое же благое и прекрасное творение, как «на Дрине Мост». ${ }^{13}$

\section{ЛИТЕРАТУРА}

Джеймс Холл. Словарь сюжетов и символов в искусстве. Перевод с английского. «Крон-пресс», М. 1999.

Иво Андрич. Мост на Дрине. Изд-во «Правда». М. 1985. Иво Андрич. Повести и рассказы. Мосты на Жепе. Серия «Мастера современной прозы». Изд. М., Радуга. 1983.

Меша Селимович. Иво Андрич (1892-1975). Предисловие к книге Иво Андрич. Повести и рассказы. Серия мастера Современной прозы. Изд-во «Радуга», М. 1983.

Энциклопедия символов. Под ред., О. В. Перзашкевича. издво ЭКСМО. М. 2007.

13 Меша Селимович. Иво Андрич (1892-1975). Предисловие к книге Иво Андрич. Повести и рассказы. Серия мастера Современной прозы. Изд-во «Радуга», М. 1983, с. 12. 
Ulfat Badalbeyli

\section{THE MOTIF OF THE "BRIDGE" IN THE WORKS OF IVO ANDRIĆ}

\section{Summary}

This article studies the works of an amazing artist - realist and psychological prose master, thinker and successful diplomate, laureate of Nobel Prize (1961) Ivo Andrić.A rich literary heritage of Ivo Andrić including poetry, prose,essay represents wonderful organic alloy of problems, issues and visions of one of the most interesting and peculiar provinces of Bosnia.

Author of " The Bridge on the Drina " studied universal human problems, moving beyond the national reality. Writer has searching for the meaning of existence of mankind in all of his compositions. He was writing about the eternal quest of humans in order to understand how the reality is supposed to be and how the people themselves are supposed to be.

The works of Ivo Andrić are well-known in Azeri literary studies. Lectures on the works of Ivo Andriç, Meša Selimović and other Balcan writers are given at the humanities departments of the Baku State University.

Key Words: Balkan literature, novel, tune, bridge, Travnik, Visegrad, Nobel laureate, Ivo Andrić, world painting, translations, azeri literary studies. 